\title{
La dimensión política de los primeros documentales del Marqués de Villa-Alcázar ${ }^{1}$
}

\author{
Marqués de Villa-Alcázarren lehenengo \\ dokumentalen garrantzi politikoa
}

\section{Political dimension in Marqués de Villa-Alcázar's first documentary films}

\section{Pedro Poyato Sánchez}

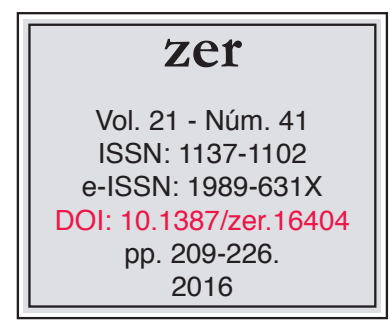

Recibido el 16 de marzo de 2016, aceptado el 26 de septiembre de 2016.

\section{Resumen}

Una de las figuras sobre la que se edifican los documentales del Marqués de Villa-Alcázar es la parábola, relato comparativo que deviene en una vía para la introducción en los filmes de un subtexto ideológico acorde con el régimen franquista. Esta componente, emanada tanto de la parábola como, en ocasiones, de comentarios relacionados con el tema del filme, permite caracterizar al documental marquesiano de propaganda política. El objetivo de este trabajo es el estudio de una muestra representativa de los primeros documentales del Marqués de Villa-Alcázar con el fin de desentrañar la carga ideológica que anida en ellos.

Palabras clave: Cine, documental, propaganda, ideología, franquismo, censura.

\section{Laburpena}

Parabola da Marqués de Villa-Alcázarren dokumentalek oinarri gisa duten irudietako bat, eta konparaziozko kontakizun hori erabili izan zen filmetan erregimen frankistarekin bat datorren azpitestu ideologiko bat sartzeko. Hala parabolatik nola, batzuetan, filmaren gaiarekin lotutako iruzkinetatik datorren osagai hori dela eta, markesari buruzko dokumental hori propaganda politiko gisa sailkatu daiteke. Lan honen helburua da Marqués de Villa-Alcázarren hasierako dokumentalen lagin bat aztertzea, horietan dagoen karga ideologikoa argitze aldera.

Gako-hitzak: Zinema, dokumentala, propaganda, ideologia, frankismoa, zentsura.

\footnotetext{
${ }^{1}$ Este trabajo ha sido elaborado en el marco del Proyecto de I+D del Programa Estatal de Fomento de la Investigación Científica y Técnica de Excelencia "La obra del Marqués de Villa-Alcázar (1934-1966): un eslabón necesario en la historia del documental cinematográfico en España", referencia: HAR2013-44310-P.

2 Universidad de Córdoba, pedro.poyato@uco.es
} 


\begin{abstract}
One of the basic elements in which rest a great deal of Marqués de Villa-Alcazar's agricultural documentary work is the parable, a short allegorical story used in these particular films as an ideological subtext in accordance with the principles of Franco's Regime. This ideological component, arising both from the parable and, sometimes, from inserted comments related to film aspects, aids to identify Villa-Alcázar's documentaries as political propaganda. The aim of this paper is to present a sample study of the first works by Marqués de Villa-Alcázar in order to disclose the ideological burden in them.
\end{abstract}

Keywords: Film, documentary, propaganda, ideology, Franco's regime, censorship. 


\section{Introducción}

Director de una obra de casi setenta documentales agropecuarios producidos por el Ministerio de Agricultura, el Marqués de Villa-Alcázar se refería así a ella:

Las primeras películas hechas bajo mi dirección fueron [...] realizadas antes de nuestra guerra de liberación. El año 1940 expuse al Subsecretario de Agricultura y a la Junta Asesora de Publicaciones y Propaganda de dicho Ministerio la idea de impulsar la realización de películas educativas, cortas y sonoras, que considero como el mejor medio de divulgación para enseñar $\mathrm{y}$ aconsejar a quienes viven por entero en el medio rural y entre quienes hay, desgraciadamente, un elevado tanto por ciento de analfabetismo (Lagarma, 1943: 50).

Proseguía así el Marqués una línea de trabajo instaurada por el Ministerio de Agricultura en 1933, cuando se crea el Servicio Central de Cinematografía Agrícola, dependiente de la Dirección General de Agricultura, por cuanto «el cine, dado el elevado porcentaje de analfabetismo que entonces había en España, era el mejor procedimiento para demostrar a los campesinos el verdadero alcance de la reforma agraria y darles a conocer todos los elementos que el Estado pone a su servicio» ${ }^{3}$. En dos años, hasta 1935, se realizaron en este sentido películas como El cultivo de arroz, La riqueza agrícola de Canarias, La elaboración de los vinos espumosos en España, Necesidad de una reforma agraria o Fumigación del naranjo, entre otras. Concebidas a modo de documentales expositivos de vocación didáctica y propagandística, en la terminología de Bill Nichols (1997: 68-69), todas estas cintas se estructuraban en torno a una voz over que, convenientemente ilustrada por las imágenes correspondientes, daba a conocer diversos aspectos relacionados con el tema en cuestión, el arroz, los vinos, el naranjo o la reforma agraria. Atendiendo a estos mismos presupuestos, las primeras películas del Marqués de Villa-Alcázar remarcaban su carácter didáctico anotando en los propios títulos de crédito su condición de charlas cinematográficas -sobre abonos, semillas o barbecho-, si bien presentaban una diferencia estructural con respecto a las anteriores, a saber, la introducción en su tejido de la parábola como elemento docente, como así lo significaba el propio Marqués de Villa-Alcázar:

Como elemento docente empleábamos la parábola. Es una orientación totalmente nueva en la técnica de la enseñanza cinematográfica, ya que en ella se utiliza por primera vez imagen de cosas de la vida corriente del campesino, para hacerle comprender ideas que, sin esa comparación, pudiera escapar a su comprensión. [...] y no sé que fuera de España se haya empleado jamás la parábola desde el punto de vista cinematográfico en la forma en que lo hacen mis filmes (1951: 312).

Aparecido en el Diario de Las Palmas, 12 de junio de 1933, p. 3, según recoge Camarero (2014: XX). 
Pues bien, estas parábolas o relatos figurados que estructuran los documentales marquesianos y de los que, por comparación con los relatos explícitos, se extrae una enseñanza ${ }^{4}$, devienen a su vez en una vía para la introducción en los filmes de una carga política notable, de un subtexto ideológico acorde con los valores preconizados por el régimen franquista, en especial los referidos a la religión y la moral cristiana, la familia y la educación. Y ello es así hasta el punto de que la componente pedagógica acaba viéndose muy disminuida en relación a la política, por cuanto esta va a resultar a la postre responsable de una buena parte de la riqueza discursiva del documental. Tan importante era para el Marqués de Villa-Alcázar la presencia en sus filmes de esta componente política, que, cuando la ocasión no resultaba propicia para la parábola, aquella era declinada bien a partir de toques religiosos y/o patrióticos -en palabras del mismo Marqués de Villa-Alcázar ${ }^{5}-$, bien a partir de comentarios introducidos a propósito de motivos más o menos colaterales al tema que intitula el filme.

Nos encontramos, pues, así con un tipo de documental expositivo de vocación didáctica, pero a la vez propagandística en el que la componente política anida, por así decir, en un segundo nivel del texto, prendida a la parábola -o desarrollada a partir de los toques o comentarios antes apuntados- en principio destinada a facilitar las enseñanzas acerca de los motivos relacionados con el campo que enuncia el título del filme. En lo que sigue, nos ocupamos de estas cuestiones pasando revista para ello a unos cuantos documentales representativos de la serie marquesiana de los años cuarenta, por ser en estos tiempos de autarquía franquista donde, como puede suponerse, más explícitamente es trabajada la componente ideológica de los filmes, entre ellos El barbecho (1941), un filme ya realizado en 1934, pero con un montaje diferente, como luego veremos; Jerez-Shérès-Sherry (1943); Naranjas, limones y pomelos (1945); Maderas de España (1945) y España se prepara (1949). La elección de esta muestra permite hacer un recorrido tanto por los tipos de parábola como por los de los comentarios trabajados, desde los alusivos a la familia o a la mujer, hasta los referidos al Alzamiento franquista. A partir de una metodología de análisis interesada tanto por el contexto de emisión como de recepción de los documentales, estudiaremos en cada uno de ellos el funcionamiento, bien de la parábola, bien de los comentarios introducidos por el narrador, con vistas a desentrañar la carga política que anida en el discurso fílmico correspondiente. Pero comencemos por situar el marco histórico y conceptual en el que brota la obra del Marqués de Villa-Alcázar.

\section{Producción documental española en los años treinta y cuarenta}

Con Las Hurdes (Luis Buñuel, 1933), un documental expositivo donde se dan cita el cine etnográfico y de denuncia social, despuntaría en el cine de la República una importante escuela documentalista de la que acabaría formando parte el Marqués del Villa-Alcázar. Interesada por las experiencias del cine educativo, la administración republicana realizó una serie de encargos destinados a la divulgación agrícola, en especial de la reforma agraria, entre ellos dos realizados a Carlos Velo y Agustín

\footnotetext{
${ }^{4}$ En eso consiste la figura literaria de la parábola (Azaustre y Casas, 1994: 21).

5 En carta enviada por el Marqués de Villa-Alcázar, en el verano de 1942, a la Censura Eclesiástica, Departamento de Cinematografía. En Archivo General de la Administración, AGA, Alcalá de Henares, caja 36/03204.
} 
G. Mantilla que darían como resultado La ciudad y el campo (1934) y Almadrabas (1934). Respondiendo al aliento republicano, ambos documentales prestaban atención al protagonismo colectivo, la cooperativa avícola y la pesquera, respectivamente, descubriéndose sus imágenes muy influenciadas por la escuela documental inglesa, en especial las del segundo de ellos, Almadrabas, claro heredero de Drifters (John Grierson, 1929), un documental que acude al encuentro del mundo real -en este caso el trabajo de los pescadores de arenque en las costas de Yarmouth y Lowestoft- tanto para extraer belleza de él como para dar cuenta de los seres anónimos que constituyen la vida de un país. Y así, nos encontramos ante documentales expositivos de vocación didáctica, como a ello contribuye la sobriedad de la voz over, que combinan en efecto la poesía visual con el comentario político, comentario que, a diferencia del de las primeras películas del Marqués de Villa-Alcázar, emana del relato explícito, esto es del confeccionado a partir de la temática principal del filme, así sea la industria del huevo de las ponedoras o la de la pesca del atún.

Con el estallido de la Guerra Civil continuó la producción de documentales, si bien las temáticas agrícolas, ganaderas o pesqueras quedaron algo relegadas en beneficio de las relacionadas con la defensa de la legitimidad de la República, la política de no intervención, la defensa de Madrid o la justificación de la sublevación militar, dependiendo, lógicamente, del bando que produjera la película. Pero se trataba en todo caso de documentales también expositivos de vocación didáctica donde la voz over combinaba, en sus comentarios dirigidos al espectador, la persuasión con la propaganda, convirtiendo en dominante una u otra, según los casos. Junto a ello, se alineaban determinadas operaciones discursivas, como la inclusión en el tejido documental, bien de escenificaciones de ficción dramatizadas, bien de imágenes de otras películas, que dieron lugar a toda una gama de variantes de documental que pueden ser puestas en relación con las que en esos mismos años empezara a trabajar el Marqués de Villa-Alcázar.

El documental anarquista La silla vacía (Valentín R. González, 1937), por ejemplo, se sirve, en su llamada desesperada a la movilización social de la retaguardia, de un personaje de ficción para protagonizar, salpicadas a lo largo del metraje, diversas escenificaciones destinadas tanto a vertebrar cuanto a dramatizar la dimensión expositiva del documental. Por su parte, Defensa de Madrid (Ángel Villatoro, 1936), un documental en dos partes producido por la Alianza de Intelectuales Antifranquistas para la Defensa de la Cultura, organización del ámbito comunista, había introducido como novedad sendos recitados de la actriz teatral Montserrat Blanch enmarcando la primera parte, y de Rafael Alberti cerrando la segunda. La presencia de Montserrat vestida de maja e interpelando al espectador viene a reforzar así la componente persuasiva de este documental de propaganda destinado a enardecer a un pueblo para que defienda la libertad, convenciéndolo a su vez de las posibilidades de éxito. En su cierre, la segunda parte de Defensa de Madrid se vale de las dramáticas imágenes del ataque aéreo sobre la capital para llamar a la población, ayudándose ahora de la presencia de un Alberti recitando con voz vibrante "Madrid, corazón de España", a la defensa de Madrid con el fin de ganar la guerra y convertir así a la ciudad en la tumba del fascismo. La palabra de la historia y la palabra poética, en sendos recitados de la actriz y del poeta, se descubren así recursos que vienen en ayuda de la voz over para fortalecer extraordinariamente la componente persuasiva del documental. 
He aquí algunas de las modalidades de documental que sirvieron de contexto a la producción marquesiana; modalidades que pueden todavía completarse si tomamos en cuenta las producciones gubernamentales y las del bando rebelde. Entre las primeras destaca España 1936 (Jean Paul Chanois, 1937), un encargo del gobierno republicano para propaganda de su causa en los países europeos. De tono esencialmente didáctico, este documental está elaborado a partir tanto de materiales de archivo, así de imágenes rodadas por Roman Karmen para noticiarios soviéticos o de imágenes tomadas de noticiarios franceses (Gubern y Hammond, 2009: 311-313), como de filmaciones muy semejantes a las trabajadas por el documental político francés y el radical americano de los años treinta, concretamente el producido por Frontier Films, productora independiente entonces presidida por Paul Strand y comprometida con las causas antifascistas (Montero y Paz, 2006: 237-238). Mezclando y ordenando imágenes fílmicas de archivo o rodadas especialmente para la ocasión, España 1936 trataba de pregonar un ideario básico -el proclamado por el gobierno republicano en los medios impresos y audiovisuales durante la contienda- que era expresado verbalmente por la voz over que preside el filme, una voz a la vez depurada y estoica que, como la de Tierra sin pan, emplea un sereno tono de neutralidad (Gubern y Hammond, 2009: 316).

España heroica (Joaquín Reig, 1937), producción documental del bando rebelde, fue la réplica a España 1936. Este documental se ocupa de contrastar la España secuestrada por el comunismo y las Brigadas Internacionales, la que quema iglesias y destruye el patrimonio, con la nueva España, la que construye lo que otros destruyen, que desfila en orden ante su caudillo y se prepara para devolver a España a su pasado glorioso. Pero lo interesante es que, junto a esta dimensión propagandística próxima al panfleto, así en el fragmento de homenaje a los caídos que cierra el filme, la película trabaja escenas de género, en concreto de cine bélico, como es el caso de los fragmentos del sitio del Alcázar o del asedio a Madrid, entre otros. Podríamos hablar por ello aquí de un documental expositivo panfletario que incluye escenificaciones de cine bélico con vistas tanto a suavizar la componente propagandística cuanto a dramatizar el relato de ciertos acontecimientos en los que la exaltada voz over calla para dar paso al sonido ambiente.

Finalizada ya la Guerra Civil, la creación del No-Do (Noticiarios y Documentales españoles), en los años cuarenta, se posicionaría como principal vehículo cinematográfico propagandístico del régimen de Franco. Su aparición generó ya expectativas acerca de su función adoctrinadora:

Nuestro cine actual debe estar en juego con la formación de la conciencia nacional [...] Simultáneamente, debe informar esta conciencia llegando a todos los españoles con la eficacia que tiene la pantalla, en el reflejo del mosaico de valores gráficos, espirituales y materiales que encierra España (Anónimo, 1943: 4).

Esta misión, que atravesaría varias etapas, desarrolla en los años cuarenta sus fórmulas más beligerantes, desde la evocación de la Guerra Civil hasta la exaltación de la 
figura de Franco, pasando por la calculada captación de un desfile o la recreación de un himno falangista. A partir de los años cincuenta, coincidiendo con el cambio de modelo económico, esta pauta propagandística del régimen pierde consistencia centrándose entonces en consignas como la celebración y apología de su transformación económica, su dinámica industrial, la creación de infraestructuras, etc. (R. Tranche y Sánchez-Biosca, 2001: 195). En sintonía con el No-Do, los documentales del Marqués de Villa-Alcázar acusarán este mismo cambio: para comprobarlo basta comparar Jerez-Xérès-Sherry, filme que abordamos más adelante, con El Jerez (1959), un filme sobre el mismo tema pero realizado dieciséis años después. De cualquier modo, nos ocuparemos en lo que sigue de los documentales del Marqués sin perder de vista este contexto documentalista en el que se inscriben.

\section{El barbecho (1934-1941): parábola y familia}

Aun cuando existen dos montajes de este filme, el primero de ellos fechado en 1934, sólo se conserva el del año 1941 (Camarero, 2014: 48). No podemos hacer por ello un estudio comparativo entre ambos, pero sí inferir que no debieron existir diferencias ideológicas de calado entre sus respectivos montajes, si tenemos en cuenta que el Marqués de Villa-Alcázar fue detenido en noviembre de 1936 bajo la acusación de pertenecer a las Juventudes de Acción Propagandística (JAP) de la Confederación Española de Derechas Autónomas (CEA). Y así vino a reconocerlo el propio Marqués algún tiempo después en carta dirigida al Presidente de la Comisión de Agricultura y Trabajo Agrícola, el 16 de julio de 1937, donde apuntaba «estar identificado con alma y vida con el Movimiento Salvador que dirige el Generalísimo desde mucho antes del 18 de julio» ${ }^{6}$.

Producido por la CEA, como también lo fueron, ese mismo año de 1934, los documentales de Velo y G. Mantilla ya citados, La ciudad y el campo y Almadrabas, El barbecho se caracteriza, como así lo ha señalado el propio Marqués de Villa Alcázar (1951: 312) por un trabajo recurrente de la parábola. Veámoslo. El filme arranca presentando el barbecho como una arma para la lucha contra el esquilmo de la tierra. A su vez, los valores nutritivos del suelo son simbolizados por los chorizos y las cosas de comer, según una comparación destinada a introducir la parábola que va a ser declinada a continuación. En torno a la mesa con viandas aparece reunida una familia: vemos al padre, Antonio, y también a la madre, quien, con su bebé en brazos, se ocupa de darle la papilla. Antonio bebe un largo trago de la bota de vino que acaba de traerle a la mesa su pequeña hija. Apunta entonces la voz over: «Del mismo modo que Antonio no puede aprovechar la riqueza de las viandas si no tiene vino, las plantas no pueden aprovechar la riqueza del suelo, si no tienen agua a su alcance. Pero, a diferencia de Antonio, las plantas no tienen manos, ni dientes; de ahí que necesiten tomar los alimentos disueltos en agua, como el bebé de Antonio». Se deriva, pues, de aquí que el elemento nutritivo de la tierra es como la papilla del bebé, mientras que las plantas son como el propio bebé.

Este relato comparativo - parábola, en la terminología que estamos utilizando- se construye, pues, en dos fases sucesivas: en la primera, las plantas son vinculadas a Antonio, en tanto que ambos necesitan para comer del líquido elemento; la segunda

\footnotetext{
${ }^{6}$ Expediente personal del Marqués de Villa-Alcázar. En Archivo del Ministerio de Agricultura, Madrid.
} 
matiza por su parte que esa agua es requerida de modos distintos por las plantas y por Antonio, dado que aquellas la necesitan para la elaboración misma del elemento nutritivo. Es entonces cuando entra en escena el bebé, por cuanto en su caso se requiere también del agua para la elaboración de la papilla, su alimento. La diferencia que se establece entre Antonio y las plantas, y que aproximan estas al bebé, es, pues, justificada a partir de que aquel tiene manos, muelas y dientes, mientras que las plantas no. Sin duda: Antonio tiene manos, pero -añadiríamos nosotros- también tiene pies, y, sin embargo, no va a por el vino, sino que ha de ser su pequeña hija quien lo traiga a la mesa. Las imágenes que ilustran este llamativo discurso de la voz narradora muestran, como ya decíamos, a una familia sentada a la mesa en la que sólo el padre tiene nombre, Antonio. La pequeña hija, ni tan siquiera mencionada, tiene como tarea acarrear a la mesa lo que el padre necesita, en este caso, la bota de vino. El bebé, por su parte, toma, feliz la papilla. Y la madre, que, tras aparecer brevemente en el plano general de la familia, fue ya desplazada fuera del campo visual cuando la cámara se dirigía a Antonio, queda ahora off al recortar el encuadre primeros planos del bebé tomando la papilla. La madre es así relegada tanto por el narrador como por la puesta en forma de las imágenes; su tarea es dar la papilla al pequeño, como la tarea de la pequeña hija es traer la bota de vino al padre. Las mujeres aparecen, pues, sentadas a la mesa, pero no comen; sólo lo hacen los hombres. Es así cómo la construcción de la parábola, destinada a una fácil comprensión por parte de los espectadores de la necesidad y utilización del agua por parte las plantas, pasa en este caso por la introducción de imágenes que construyen un discurso ideológico en torno a un modelo de familia que claramente relega a las mujeres, quienes, además de ignoradas, están destinadas a tareas exclusivamente al servicio de los hombres: del hijo, en el caso de la mujer, y del padre, en el de la pequeña hija.

Un segmento posterior arranca mostrando al campesino arando, los planos más cercanos detallan cómo la tierra se rompe al paso de las cuchillas del arado, mientras que un terruño es el motivo que sirve para mostrar la humedad retenida por la tierra. «Humedad -advierte la voz narradora- que aprovechará la próxima cosecha si no la roban antes las malas hierbas, que son como esos mozos holgazanes que no trabajan, que no sirven para nada bueno, y que al menor descuido del ama de la casa se meten en la cocina con malas intenciones, se beben el vino, se llevan las viandas y si no arramblan con la chica de la casa es porque ella no se deja». He aquí una nueva parábola ilustrada en este caso por una concatenación de imágenes protagonizadas por el vago, un joven que, tendido en la hierba a la sombra de un árbol, aprovecha que el ama abandona la casa para introducirse en ella y proceder según lo relatado por el narrador: beberse el vino, echarse a la faja los chorizos y abordar a la joven, quien se defiende del intruso enarbolando una sartén. Finalmente, al percatarse de la vuelta del ama, el vago abandona la casa a toda velocidad. Es así cómo, para explicar los efectos dañinos de las malas hierbas, el documental introduce esta parábola anterior, un relato de corte humorístico que, como con perspicacia ha señalado Ana Melendo (2013: 87), encuentra su filiación en los sainetes cinematográficos de Filmófono de esos mismos años, tanto por lo que se refiere a los personajes y sus tipos, como a la interpretación y a la propia situación en su conjunto.

Nuevas imágenes se ocupan otra vez del campesino, en este caso trabajando con el escarificador, inmerso en una tarea ilustrada mediante un esquema que explica 
cómo germina y crece la mala hierba, y cómo el escarificador destruye su raíz, evitando así que la humedad permanezca en el suelo; humedad que, anticipa la voz over, encuentra ahora su equivalente en la joven mujer, mantenida a buen recaudo por la madre, o más exactamente por su escoba, encargada tanto de echar a los vagos de la casa, como de librar a la hija de todos aquellos que puedan rondarla. Pero lo más interesante de este discurso de la voz narradora es cómo conjuga, en su final, esta asociación entre la humedad y la mujer. Así, si en la primera parte de su enunciado «para retener la humedad del suelo, ansiosa de escaparse a que la ronden los rayos del sol» se refiere a la humedad de la tierra, en la segunda «y que, bien guardada en la casa, tendrá más adelante una misión más útil y feliz» se refiere a la mujer, una y otra aunadas por la conjunción copulativa. E inmediatamente después completa la parábola en todos sus términos: «Y no olviden tampoco que el escarificador cierra la puerta a los vagos y malas hierbas - un plano detalle subraya cómo el cerrojo cierra la puerta- que esperan llevarse a la moza, a la humedad del suelo, que tanta falta nos hace. Y de ese modo la obligan a quedarse en casa, en su sitio, para que la utilice la cosecha próxima que vendrá a buscarla de la misma manera que este mozo, sano y trabajador viene a buscar a la moza bien guardada». Las imágenes que ahora ilustran esta parte muestran al mozo sano y trabajador llegando hasta la casa, donde se encuentra con la joven -obsérvese cómo el narrador ha especificado sin ambages que el sitio de la mujer, de la moza, está en la casa-, en un plano al que sigue otro de la pareja ya junta mientras es observada, a través de sus sombras proyectadas en la pared, por una complaciente madre, tal y como se aprecia en la Figura 1:

Figura 1. Complaciente madre.

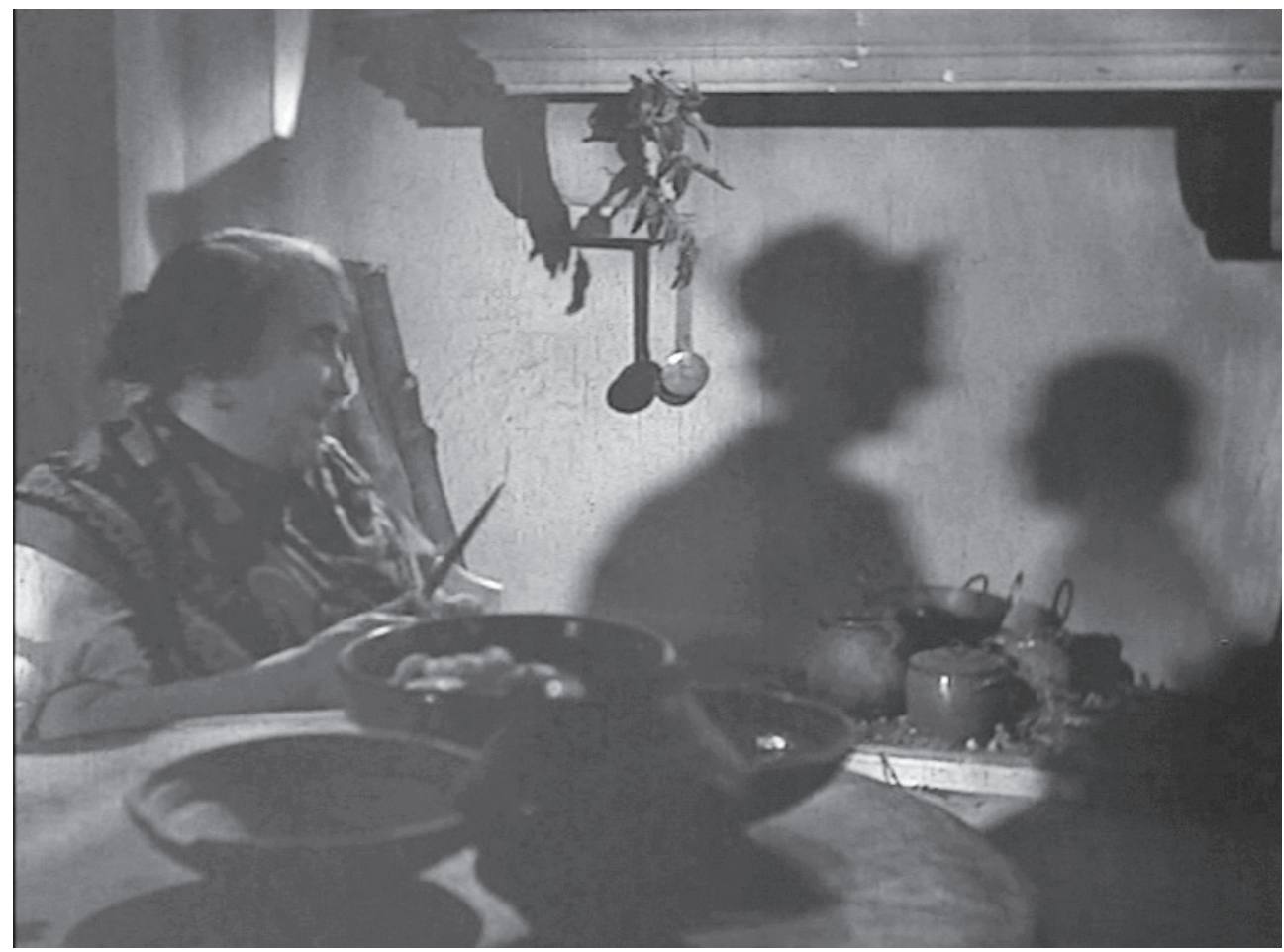


Es este un plano que demuestra la capacidad de síntesis de un cineasta que opta por mostrar a la madre junto a su gran obra, materializada esta en el dibujo de las siluetas de los cuerpos de los jóvenes ya juntos. Un nuevo y definitivo elemento se añade así a la historia para completar la parábola en todos sus términos: el mozo sano y trabajador asociado a una cosecha que ella (la humedad, la mujer) hará buena y abundante.

El documental concluye con las imágenes de una plantación de trigo, las espigas en flor mecidas por el viento, donde aparece, feliz y sonriente la nueva pareja, a la que no tarda en añadirse un pequeño que, aparecido de entre los propios trigales, él toma en sus brazos (Fig. 2), mientras que la voz over insiste a su vez en la prosperidad y la felicidad que, si esperan con paciencia y trabajan con fe, merecen los campesinos españoles. A la introducción de la buena madre y su tarea, en este caso guardando la casa y manteniendo a la hija a buen recaudo, se añade ahora la del mozo sano y trabajador posibilitando de este modo ese desenlace edulcorado y feliz que une cosecha (en extremo abundante) y familia (en extremo feliz).

Figura 2. Cosecha y familia: prosperidad.

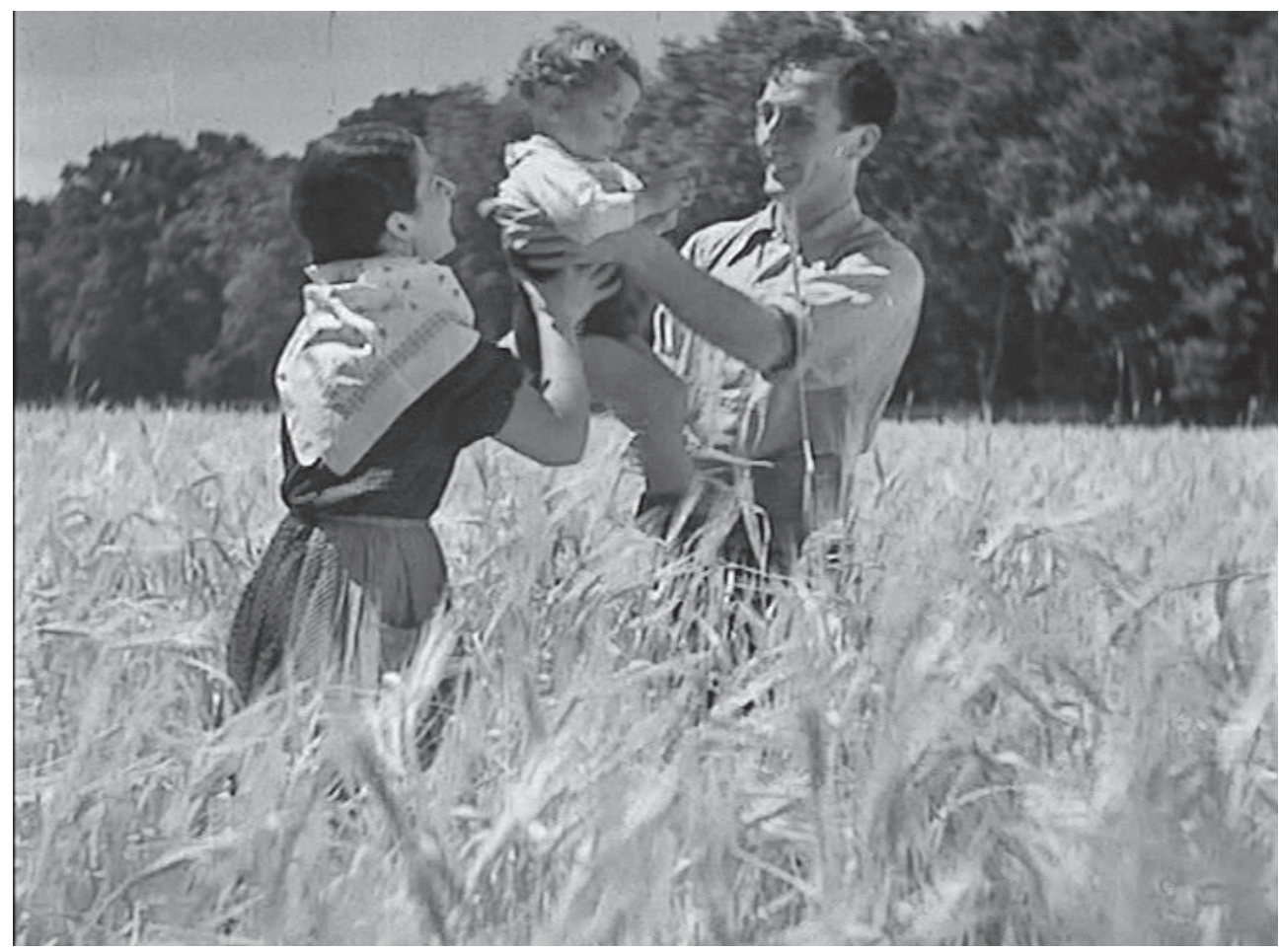

Y así, el empleo de la figura de la parábola, materializada en los relatos figurados anteriores desplegados en torno a la familia y las funciones que han de desempeñar cada uno de sus miembros, en especial la madre, en un filme cuyo tema es el barbecho posibilita al narrador construir un modelo de familia bien próximo al que iba a imponer el franquismo una vez acabada la Guerra Civil, modelo al que se han referido algunos historiadores: 
Una vez terminada la Guerra Civil, la familia fue uno de los pilares fundamentales de la reconstrucción del tejido social que impuso el franquismo. Por supuesto, un concepto de familia que respondía a coordenadas católicas y tradicionales donde la mujer tenía un rol muy definido: esposa y madre. Este era, se afirmaba, el fin último de la buena española (Gil y Gómez, 2010: 460).

El prototipo masculino franquista evocaba al varón, cabeza de familia, emulando a Franco como jefe y cabeza del estado y figura incuestionable de autoridad patriarcal, como contrapartida se consagró el modelo de mujer prolífica, sumisa y piadosa [...] convertida en madre y guardián de la familia (Nash: 2015: 193).

De este modo, El barbecho, adelantándose a la época por venir, trabaja un modelo de familia que, como podrá constatarse en películas posteriores, cobraría plena actualidad en los documentales realizados por el Marqués de Villa-Alcázar a lo largo del régimen franquista, en especial los años cuarenta. Modelo de familia que moviliza, como es fácil colegir a partir de lo señalado, una postura que permite caracterizar a El barbecho como un documental expositivo de divulgación agrícola cuya componente educativa encierra a su vez una fuerte carga de ideología política. En esto se diferencia, precisamente, de los documentales de Velo y G. Mantilla ya referidos, por cuanto en estos la carga ideológica, el protagonismo colectivo de esos seres anónimos que protagonizan la vida de un país, emana, a la vez que la componente didáctica, del relato primero, no del figurado.

\section{Jerez-Xérès-Sherry (1943): parábola y educación}

La copia disponible de este filme es una adaptación al castellano de un original hecho y pensado en inglés, por estar destinado Jerez-Xérès-Sherry a mercados exteriores, en concreto Estados Unidos e Inglaterra. El propio Marqués de Villa-Alcázar (1951: 312-313) ha comentado que la película fue así concebida para contrarrestar la intensa propaganda americana, principalmente de Bodegas California, con vistas a vender, para la exportación, vinos de Jerez. Se trata en efecto de combatir la propaganda americana volcándose para ello en demostrar que el utillaje y los métodos más modernos utilizados para la obtención del vino californiano redundan no en la calidad de los caldos obtenidos, sino en la cantidad:

Los tractores producen cantidad pero no calidad. Entonces metemos la idea comparativa: calidad $=$ obra de arte presentando a continuación el artista haciendo una obra de arte y los obreros cavadores haciendo lo preciso para conseguir vino de Jerez, al cual ya calificamos como obra de arte (VillaAlcázar, 1951: 314).

Atendiendo a esos presupuestos, uno de los segmentos plásticamente más bellos del filme se interesa por la cava a mano de los viñedos, el contrapicado realza las figuras de los cavadores (Fig. 3), su vista fija en el borde de la herramienta, su esfuerzo 
bajo el cielo de bochorno de Andalucía, tachados de artistas por la voz over en un discurso que conjuga en clave poética el músculo como herramienta humana con el vino como obra de arte. Y así, frente a los modernos tractores con que en California labran sus viñedos, comparados con las copias que da la imprenta al reproducir una imagen, aparecen los cavadores españoles, cuyo esfuerzo es comparado al del pintor que con su vista puesta en el pincel da el toque artístico a su obra única. Tal es en efecto la parábola de la que, como dice el Marqués de Villa-Alcázar, se sirve el filme para destacar la calidad del vino español frente al americano.

Figura 3. Cavador bajo el cielo de Jerez.

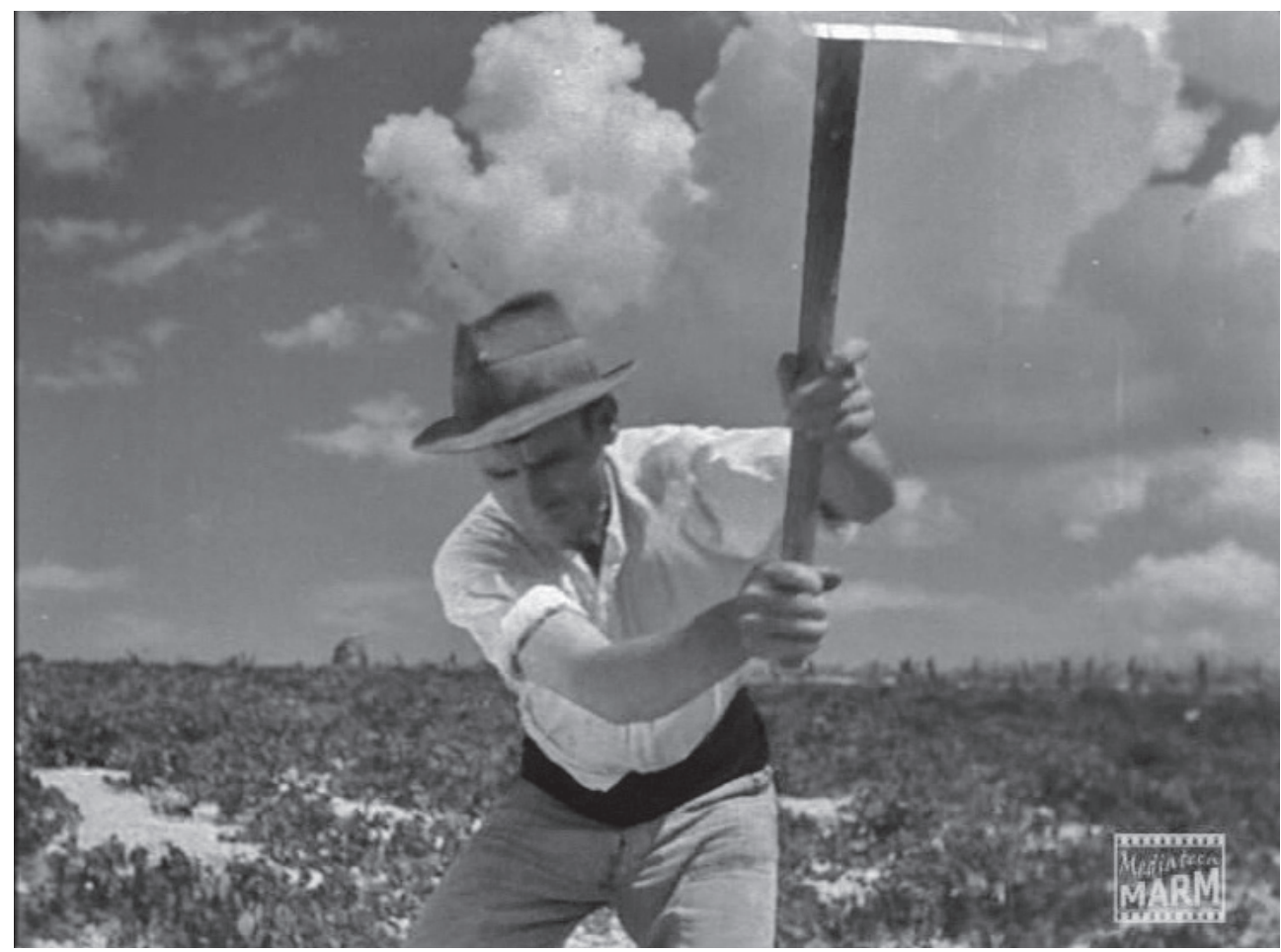

Pero nada refiere, sin embargo, el Marqués acerca de esa otra gran parábola del filme que trabaja la comparación entre el vino y el hombre, a propósito de la educación: «El vino joven entra en la solera para recibir su educación, del mismo modo que los parvulitos entran en su primera clase sabiendo muy poco». Palabras de la voz narradora que son el comienzo de una parte del documental donde la producción del vino deja paso a la educación de los niños españoles, parte que llega a constituirse propiamente en un micro-documental dentro del documental. En él, las imágenes muestran a los escolares en sus centros practicando diversos deportes a partir de una operación de montaje rápido que se ralentiza extraordinariamente cuando aparece el plano de una bandera española en el mástil acompañando las palabras de la voz over: «bajo los ideales de la patria». A este plano le sigue otro de jóvenes perfectamente alineados y en posición de firme mientras oímos: «aprenden la disciplina», y finalmente 
otro de composición idéntica al anterior pero presidido por un cura santiguándose, acompañando el enunciado de la voz over: «a amar a Dios». Nos encontramos, pues, aquí ante una concatenación de imágenes que se limitan a ilustrar las palabras de una voz narradora que parece olvidarse del motivo principal del documental -el proceso de maduración de los vinos- para introducir, haciendo uso de la parábola, un discurso sobre la educación de los jóvenes españoles en torno a tres pilares fundamentales, el deporte, la disciplina militar, y la religión, todo ello bajo los ideales de la patria.

Si se revisan los documentos de la época, puede constatarse que la práctica del deporte, o más exactamente, de aquello que el franquismo llamó educación física, ejercitaba a los jóvenes, tanto a las mujeres, quienes conseguían desarrollar una constitución física fuerte que les permitiera engendrar hijos sanos y robustos (Zagalaz, 2001: 8), como a los hombres, así forjados para la disciplina militar y para suscitar en ellos el amor a la Patria y a Dios ${ }^{7}$. De la mano de la ideología de la Cruzada entendida como conquista de una catolicidad que se había perdido, el franquismo iniciaría a comienzos de los años cuarenta una importante campaña de rearme moral en la vida y costumbres, sobre todo de los jóvenes, para la España nacida de la Guerra Civil. Pues bien, valiéndose de la parábola, el documental Jerez-Xérès-Sherry se hace eco, en segmentos como el anterior, de estos presupuestos, convirtiéndose así en instrumento al servicio de la propaganda ideológica del régimen en su tarea de regenerar a los jóvenes; regeneración que pasa en primer lugar por una educación volcada en la consolidación de principios como la obediencia, la disciplina y el servicio y el amor a la Patria y a Dios, que eran los valores considerados como fundamentales para la consolidación del Movimiento. De este modo, la ideología del nuevo régimen fecunda el tejido fílmico documental generando un discurso donde la pedagogía sobre el proceso de obtención de los vinos de Jerez abre paso, utilizando como coartada la parábola, a la componente política y de propaganda.

De la importancia que el aparato del propio régimen concedía a segmentos ideológicos como el anterior da buena cuenta la confrontación que este documental mantuvo con la censura. En primer lugar, resulta llamativo que el Marqués de VillaAlcázar, como más arriba apuntábamos, no se refiriera en sus escritos a esta parábola anterior, muy probablemente por que no quería aludir -ni mucho menos desvelar- a su fuerte carga ideológica, pero se nos antoja que también, y sobre todo, por los problemas que la película tuvo con la censura. Que Jerez-Xérès-Sherry hubo de ser modificada en los términos establecidos por los comités de censura, es buena prueba la carta que el Marqués de Villa-Alcázar escribió, valiéndose de sus influencias, a Antonio Fraguas, a la sazón Presidente de la Comisión Nacional de Censura, a propósito del rodaje de su siguiente película Trigo en España (1943):

Después del tropiezo que sufrió mi película Jerez-Xérès-Sherry (que me ha dado bastante guerra para arreglarla de acuerdo con lo que hablamos) le envío para censurar esta película sobre el trigo con verdadero pánico ${ }^{8}$.

\footnotetext{
${ }^{7}$ Como deja bien sentado José Moscardó cuando apunta que se ha de fomentar y facilitar la práctica del deporte por cuanto «los jóvenes tienen la fe puesta en hacerse fuertes y sanos para mejor servir a España y con más eficacia y alegría morir por ella» (1941: 22-23).

8 Carta manuscrita. En Archivo General de la Administración, AGA, Alcalá de Henares, caja 36/03204.
} 
Si bien no hemos encontrado ningún documento que indique cuál fue exactamente ese tropiezo y el arreglo que fue necesario hacer, el acceso a los distintos expedientes que existen sobre la película nos ha permitido formular algunas hipótesis sobre ello. Con fecha de entrada 22 de abril de 1938, el Marqués de Villa-Alcázar envía a Censura del Cuartel General del Generalísimo en Salamanca copia del boceto del guión, donde se indica:

Varias escenas de lagar, prensado, y bastante de "soleras" con dibujo animado que explique la marcha del vino en las mismas y probablemente otro dibujo animado que mediante el símbolo que se elija (probablemente las distintas clases de un colegio) enseñe cómo el vino nuevo "aprende" del vino viejo. - Escenas de mezclado, de cata, la venencia, tipos, almacenes, laboratorios, etc. ${ }^{9}$

En el guión se apunta, pues, el método por el que va a enseñarse que el vino nuevo aprende del viejo: probablemente, se dice, a través de las distintas clases de un colegio, y recurriendo al dibujo animado. Pero el proyecto se paraliza hasta 1941, concretamente hasta el 28 de marzo de este año, fecha en la que el Marqués de VillaAlcázar dirige una nueva solicitud a la Censura, ateniéndose ya a la normativa de Orden de 15 de julio de 1939, para la autorización del guión, y en la que se insiste en la utilización de dibujos animados para ilustrar el funcionamiento de las soleras ${ }^{10}$. La Comisión de Censura da el visto bueno para la realización de la película, aunque observa que es necesario recabar previamente un informe sobre la producción de vinos en la zona de Jerez. Pero no apunta nada más. El proyecto vuelve a paralizarse otra vez hasta que más de dos años después de aprobado el guión, concretamente el 18 de mayo de 1943, es finalmente solicitado el definitivo permiso de rodaje. Mas el resultado ya lo sabemos: los dibujos animados fueron sustituidos por la filmación, como hemos visto en el segmento antes analizado, allí donde se ponían de manifiesto las enseñanzas del franquismo. Cabe, pues, suponer que a la Censura no gustó que asunto tan serio como la educación de los españoles fuera expuesto mediante el dibujo animado, sugiriendo por ello sustituir el dibujo por la filmación, además de que se completara la educación en los colegios españoles con imágenes alusivas al deporte, la disciplina militar y el amor a Dios ${ }^{11}$. Y quizá por esto mismo, porque solo importaba la propaganda ideológica del régimen -y su transmisión de modo persuasivo al espectador-, se eliminó del filme el último de los puntos reseñado en el guión, destinado a fomentar el turismo mediante la propaganda de la ciudad de Jerez.

Además de dar cuenta de la férrea disciplina implantada por el régimen en relación con la puesta en imágenes de carga política subyacente en los documentales,

\footnotetext{
9 Archivo General de la Administración, AGA, Alcalá de Henares, caja 36/04549, expediente 386.

${ }^{10}$ Archivo General de la Administración, AGA, Alcalá de Henares, caja 36/04549, expediente 386.

${ }^{11}$ Es verdad que la animación era un recurso habitual en los documentales pedagógicos de estos años (de hecho el propio Marqués los solía utilizar en sus filmes), pero no para ilustrar asunto tan importante como la educación de los buenos españoles (el fragmento conjuga desde la bandera hasta una estatua del mismo Franco) en un filme documental filmado, no de animación.
} 
este hecho anterior marcaría a fuego la trayectoria del Marqués de Villa-Alcázar, siempre temeroso ya de que, como en este caso, la Censura pudiera modificar los filmes con vistas a fomentar la postura militante de los mismos. Algo que no deja de resultar llamativo, desde luego, dada la ideología política del director, cuya adhesión inquebrantable al régimen de Franco y a su Movimiento Salvador había dejado por escrito en la carta dirigida al Presidente de la Comisión de Agricultura y Trabajo Agrícola antes referida.

\section{Naranjas, limones y pomelos (1945), España se prepara (1949) y Maderas de España (1945): educación de las jóvenes, natalidad y Movimiento Salvador de España}

Venimos constatando cómo la parábola, en principio destinada a facilitar una enseñanza acerca del funcionamiento del barbecho o del proceso de maduración de los vinos de Jerez, deviene en un relato figurado sobre un determinado modelo de familia o sobre la educación de los buenos españoles, relato figurado -rasgo estructural diferenciador, como venimos viendo, del resto de los documentales de propaganda producidos en este contexto- que es por ello el portador de una carga ideológica emanada del doctrinario franquista. Pero esta postura era también promovida por los documentales del Marqués de Villa-Alcázar a partir del toque religioso y/o patriótico. Tal es el caso, por ejemplo, de Naranjas, limones y pomelos, filme en el que a propósito de la exportación de estos frutos, la voz over apunta que con una parte del dinero así obtenido, el Sindicato Vertical de Frutos y Productos Hortícolas «proporciona descanso, instrucción y recreo a infinidad de chicas de las zonas productoras en cuyas caras la alegría y la salud ponen destellos que compensan cualquier sacrificio».Arranca entonces una parte del documental que se aparta de la línea general del mismo -la exportación de frutos- para mostrar las imágenes esas chicas españolas, uniformadas todas ellas, rezando una oración, ejercitándose en la educación física y dándose un baño.

Según antes apuntábamos, no se vale en este caso el documental de la parábola, como sucedía con la educación de los jóvenes españoles en Jerez-Shérès-Sherry, sino de una anécdota derivada del dinero obtenido de la exportación de los frutos para referir la educación de las chicas españolas, su instrucción y recreo, en lo que no es sino una modalidad más de esos cursos de adoctrinamiento llevados a cabo por las falangistas para, inspirándose en el nacionalcatolicismo, instruir a las mujeres. Teresa Loring se ha referido a este destino de la mujer:

Este destino manifiesto de la mujer se instruía a través de dos vías fundamentales; el amor y el noviazgo. El principal vehículo de difusión de este ideario lo proporcionaba la Sección Femenina que facilitaba las labores de control y adoctrinamiento ideológico de la mujer (Loring, 2003: 55).

Como hemos constatado, Naranjas, limones y pomelos da cuenta de la regulación de los aspectos de la vida cotidiana de la mujer, desde el vestuario, hasta la estética 
o la conducta: educadas en un pudor extremo -ni siquiera pueden vestir el bañador cuando se dan el chapuzón-, y conviviendo alejadas de cualquier tipo de presencia masculina, sus caras alegres compensan, matizaba el narrador, «cualquier sacrificio». Un fuerte control social preside, pues, la educación de estas jóvenes mujeres en aras de la preservación de su pureza y el amor a los varones con vistas a desempeñar, en la unidad familiar, un rol social basado en la sumisión y el decoro. He aquí cómo aflora una componente política del documental que, apartándose una vez más de las enseñanzas sobre los frutos referidos en el título, esto es, del relato explícito, se interesa, pero sin apoyarse ahora en la parábola, por transmitir de modo persuasivo al espectador una postura franquista referida en este caso a la educación de las jóvenes mujeres.

Por su parte, en España se prepara, otro de los documentales marquesianos al que queremos referirnos, la voz over advierte, en un momento dado, de que «es de extrema urgencia que España se prepare para alimentar a la avalancha de niños que Dios nos envía que hacen crecer vertiginosamente nuestro censo». Palabras estas que son a su vez ilustradas con imágenes de primeros planos de niños sobre los que se impresiona, en cifras, la población española, a lo largo de las últimas décadas. La natalidad se convierte así en el tema protagónico tanto de este segmento como también del que cierra el documental, concretamente allí donde, al hilo de la vida bucólica a la que invitan los nuevos pueblos de colonización, la voz over apunta: «Ya hay ropitas de niño colgadas al sol y las veletas -plano de una de ellas- indican que en España los vientos soplan en buena dirección». Lo importante es, pues, que nazcan niños, cuantos más mejor, pues ello quiere decir que España va bien. En este sentido, conviene recordar el pronatalismo franquista, campaña que pretendía, como ha señalado Mary Nash, «defender los intereses nacionales y la civilización occidental mediante la maternidad prolífica» (2015: 202), añadiendo:

Aunque estas políticas públicas pronatalistas afectaban directamente al cuerpo de las españolas, ellas no tenían voz en su elaboración. En efecto, las mujeres quedaron politizadas a través de un destino común determinado por su capacidad reproductora. Con una maternidad impuesta, en la posguerra, fueron secuestradas por el interés del estado en promover el cuerpo reproductor femenino como salvador de la patria y la españolidad (2015: 203).

Puede entenderse ahora en toda su magnitud lo apuntado por la voz narradora allí donde, sin necesidad de construir ya, amparándose en la parábola, un relato figurado, ni tan siquiera de apartarse del relato explícito, señala, convencida -haciéndose así eco de lo preconizado por la voz del régimen franquista, esto es, deviniendo en portavoz del mismo- que, si nacen niños, España va bien, aunque para ello -añadiríamos nosotrosla voluntad de las mujeres, e incluso del varón, hayan de ser secuestradas en aras de los intereses del Estado. Pero la componente de propaganda política de aquí emanada se prolonga ahora en la caracterización que del Alzamiento como Movimiento Salvador de España hace la voz over: «El factor primordial de toda colonización es el hombre para el que se construyen a ritmo creciente pueblos alegres, donde su vida y la de sus familias alcance el nivel que impone el Movimiento Salvador de España». La alegría 
aparece, pues, en primer término, la de los pueblos alegres conviviendo en armonía, como también el nivel que han de alcanzar sus familias, según impone el Movimiento Salvador de España, ese Movimiento que, además de salvar a España de la turba comunista, impone ahora la colonización para volver a salvarla, en este caso a sus pueblos y sus gentes de la pobreza.

Pero el Movimiento Salvador de España, asunto recurrente en los documentales del Marqués de Villa-Alcázar, había sido ya introducido en una película anterior, Maderas de España (1945), en este caso a propósito de la repoblación de los bosques. Apuntaba en este sentido el narrador: «Y así vemos árboles jóvenes que van embelleciendo los paisajes españoles de la frontera norte de Pontevedra y de la ría de Arosa, y paisajes de Vizcaya y de Santander y de tantas y tantas regiones españolas en las que, además de estar creándose una enorme riqueza para el porvenir, se crea belleza que nos haga elevar el espíritu y dar gracias a Dios, que nos permite rehacer lo que la codicia de antaño destruyó». En sintonía con lo proclamado por la voz over de España heroica, filme ya referido de producción franquista realizado en plena guerra civil, el narrador de Maderas de España sigue insistiendo, por mucho que hayan transcurrido ya ocho años, en la división de los españoles en constructores y destructores, en unas palabras que no sólo justifican el Alzamiento Nacional como Movimiento Salvador de España, sino que a su vez vinculan a Dios con Franco. En efecto, demos gracias a Dios -viene a decir la voz que narra el filme- porque nos permite rehacer (a nosotros, los españoles que, capitaneados por Franco, ganamos la guerra) lo que la codicia (de los otros, los que perdieron la guerra) destruyó (el paisaje español, o sea España).

\section{A modo de final}

En los documentales agropecuarios del Marqués del Villa-Alcázar se advierte, pues, una fuerte componente político-ideológica acorde con los valores preconizados por el régimen franquista, básicamente la familia, la religión, la patria y la educación de los españoles y las españolas. Una componente política que se filtra en el filme, bien a partir de la parábola, amparándose en que se trata de un recurso didáctico, bien a partir de los comentarios de la voz over al hilo de algún motivo más o menos relacionado con el producto o tema protagónico del filme, ya sean los frutos de exportación, los pueblos de colonización o la repoblación de los bosques. Y así, junto al didactismo sobre el campo y sus productos, estos documentales son importantes por cuanto demuestran hasta qué punto devienen también en reflejo político de una época de la historia de España fuertemente condicionada y aleccionada por el régimen franquista. 


\section{Referencias bibliográficas}

Anónimo (1943). No-Do o el periodismo español en el celuloide. Primer Plano, 120, 3-10.

AZAUSTRE, A., y Casas, J. (1994). Introducción al análisis retórico: tropos, figuras y sintaxis de estilo. Santiago de Compostela: Universidad de Santiago de Compostela.

CAMARERO, F. (2014). Catálogo de Documentales Cinematográficos Agrarios (1895-1981). Madrid: Ministerio de Agricultura, Alimentación y Medio Ambiente.

GIL, F., y GÓMEZ, S. (2010). Mujer, noviazgo y censura en el cine español (19391959). Revista Latina de Comunicación Social, 65, 460-471. doi: 10.4185/ RLCS-65-2010-912-460-471.

GUBERN, R., y HAMMOND, P. (2009). Los años rojos de Luis Buñuel. Madrid: Cátedra.

LAGARMA, J. (1943). El cine como medio de divulgación ganadera. Ganadería, 4, 49-57.

LORING, T. (2003). La Sección Femenina y la promoción de la mujer. En P. Primo de Rivera (eds.), Recuerdo de José Antonio (pp. 52-66). Madrid: Barbarroja.

MARQUÉS DE VILLA-ALCÁZAR (1951). El cine aplicado a la divulgación agrícola. Revista Española de Pedagogía, 34, 311-320.

MELENDO, A. (2013). Catequesis y vitaminas a pie de barbecho: la mujer en las primeras charlas cinematográficas del Marqués de Villa-Alcázar. En F. J. Gómez Tarín, y N. Parejo (coords.), Discursos y narraciones en el documental rural: el Marqués de Villa-Alcázar (pp. 73-92). Tenerife: Cuadernos Artesanos de Latina.

MONTERO, J., y PAZ, Ma A. (2006). España 1936. Doc On-line, 1, 234-238.

MOSCARDÓ, J. (1941). El poder educativo del deporte. Revista Nacional de Educación, 1, 22-23.

NASH, M. (2015). Vencidas, represaliadas y resistentes: las mujeres bajo el orden patriarcal franquista. En J. Casanova (eds.), 40 años con Franco (pp.191-228). Barcelona: Crítica.

NICHOLS, B. (1997). La representación de la realidad. Cuestiones y conceptos sobre el documental. Barcelona: Paidós.

RODRÍGUEZ TRANCHE, R., y SÁNCHEZ-BIOSCA, V. (2001). No-Do. El tiempo y la memoria. Madrid: Cátedra.

ZAGALAZ, $M^{\mathrm{a}}$ L. (2001). La educación física durante el franquismo. La Sección Femenina. Apuntes Educación Física y Deportes, 65, 6-16. 